\title{
Facilitating Production of Rice Dreg Peptides via Lactic Acid Bacterial Fermentation on Anti-Hypertension Efficacy
}

Chia Chi Chen ${ }^{1 \#, ~ Y i n ~ S h e n ~ L i n ~}{ }^{2 \#, ~ C h i e n ~ C h a o ~ C h i u ~}{ }^{1}$, Yi Tsz Liu ${ }^{2}$, Ruei Chen Hung ${ }^{1}$, Cho Lin Li ${ }^{1}$, Ying Ching Hung ${ }^{1}$, Chia Yu Lin ${ }^{1}$, Tzu Yun Chi ${ }^{1}$, Ya Peng Wang ${ }^{2}$, Hung Chiao Lai ${ }^{2}$, Meng Ting Wang ${ }^{2}$, Wen Lin Lai ${ }^{3,4}$, Wei Huang Tsai ${ }^{6}$, Ching Feng Chiu ${ }^{7}$, Jyh Shiun Lin ${ }^{1}$, Meng Hwan Lee ${ }^{2 *}$ and Shao Wen Hung ${ }^{1,5 *}$

${ }^{1}$ Division of Animal Industry, Animal Technology Laboratories, Agricultural Technology Research Institute, Xiangshan, Hsinchu 300, Taiwan

${ }^{2}$ Division of Animal Technology, Animal Technology Laboratories, Agricultural Technology Research Institute, Xiangshan, Hsinchu 300, Taiwan

${ }^{3}$ Department of Medical Laboratory and Biotechnology, Chung Shan Medical University, Taichung, Taiwan

${ }^{4}$ Clinical Laboratory, Chung Shan Medical University Hospital, Taichung, Taiwan

${ }^{5}$ Nursing Department of Yuanpei University, Xiangshan, Hsinchu 300, Taiwan

${ }^{6}$ Department of Science and Technology, Council of Agriculture, Executive Yuan, Taipei 100, Taiwan

${ }^{7}$ Graduate Institute of Metabolism and Obesity Sciences, College of Nutrition, Taipei Medical University, Taiwan

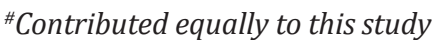

*Corresponding author: Meng Hwan Lee, Division of Animal Technology, Animal Technology Laboratories, Agricultural Technology Research Institute, Taiwan

Shao Wen Hung, Division of Animal Industry, Animal Technology Laboratories, Agricultural Technology Research Institute, Taiwan

\section{ARTICLE INFO}

Received: 幽 May 15, 2019

Published: May 22, 2019

Citation: Chen CC, Lin YS, Chiu CC, Liu YT, Hung RC, Li CL, Hung YC, Lin CY, Chi TY, Wang YP, Lai HC, Wang MT, Lai WL, Tsai WH, Chiu CF, Lin JS, Lee MH, Hung SW. Facilitating Production of Rice Dreg Peptides via Lactic Acid Bacterial Fermentation on Anti-Hypertension Efficacy. Biomed J Sci \& Tech Res 18(2)-2019. BJSTR. MS.ID.003121.

Abbreviations: ANOVA: Analysis of Variance; ATRI: Agricultural Technology Research Institute; BUN: Blood Urea Nitrogen; BW: Body Weight; CRE: Creatinine; IACUC: Institutional Animal Care and Utilization Committee; $\mathrm{IC}_{50}$ : Half Maximal Inhibitory Concentration; p.o.: Oral administration; GOT: Glutamic-Oxaloacetic Transaminase; GPT: Glutamic-Pyruvic Transaminase; SD: Standard Deviation; SEM: Standard Error of the Mean; SHR: Spontaneously Hypertensive Rats; WKY: Wistar Kyoto
ABSTRACT

Rice (Oryza sativa L.), a second major crop production in the world, is a staple food for more than 100 countries. Rice Dreg Peptides (RDP), which is the cheap by-product of rice syrup, contains more than $50 \%$ protein content and is used as a protein source. The natural food sources and their by-products have also been reported that possessed various regulation of physiologic and biologic functions. At present, a number of chemicals have been effectively used for anti-hypertension. However, there are numerous side effects associated with them. Therefore, the aim of this study was the investigation of the anti-hypertensive effect of RDP via lactic acid bacterial fermentation by using in vitro Angiotensin I-Converting Enzyme (ACE) inhibitory assay and in vivo animal experiment with Spontaneous Hypertension Rats (SHRs). In vitro results were shown that the most ideal fermentation conditions: fermentation time, $\mathrm{pH}$ value, and bacterial concentrations are $48 \mathrm{~h}, 5.17$, and $3.6 \times 10^{9} \mathrm{CFU} / \mathrm{mL}$, respectively.

According to the most ideal fermentation conditions, the concentrations of RDP (mg/ $\mathrm{mL}$ ) under three fermentation time were respectively calculated: $24.14 \pm 0.09$ (fermentation at $0 \mathrm{~h}$ ), $31.79 \pm 0.42$ (fermentation at $24 \mathrm{~h}$ ), and $30.62 \pm 0.26$ (fermentation at $48 \mathrm{~h}$ ). In addition, the anti-hypertensive effect of RDP by using in vitro ACE inhibitory assay was presented that $79.34 \pm 4.61 \%$ at $0 \mathrm{~h}$-fermentation, $84.78 \pm 7.72 \%$ at $24 \mathrm{~h}$-fermentation, and $96.70 \pm 5.85 \%$ at $48 \mathrm{~h}$-fermentation. On the other hand, the once per day-oral administration (p.o.) experiments with RDP in two doses were conducted using 6-8 weeks old SHRs. Thirty-five SHRs were randomized into 4 groups [negative control group: 5 rats; positive control group ( $20 \mathrm{mg} / \mathrm{kg} /$ day nifedipine administration): 10 rats; $\mathrm{RDP}_{\text {low }}$ group (50 mg/kg RDP): 10 rats; $\mathrm{RDP}_{\text {high }}$ group (200 mg/kg RDP): 10 rats] according to blood-pressure level. Ten Wistar Kyoto (WKY) rats were blank normal control group. RDG was administrated by p.o. through gavage per day for 2 months. The blood pressure values were measured for each group once a week.

In vivo results were presented that the blood pressure of SHRs before and after experiment in four groups were respectively $181.20 \pm 5.51 \mathrm{mmHg} ; 192.20 \pm 3.92 \mathrm{mmHg}$ (negative control group), $170.50 \pm 3.49 \mathrm{mmHg} ; 129.44 \pm 3.80 \mathrm{mmHg}$ (positive control group), $171.40 \pm 5.29 \mathrm{mmHg} ; 167.00 \pm 0.92 \mathrm{mmHg}\left(\mathrm{RDP}_{\text {low }}\right.$ group), and $169.70 \pm 6.69$ mmHg; $159.70 \pm 1.01 \mathrm{mmHg}\left(\mathrm{RDP}_{\text {high }}\right.$ group). The mean blood pressure in two RDP groups was significantly lower than negative control group. Moreover, 4 indexes of the liver and kidney functions of RDP-administrated SHRs were located at the normal levels. In conclusions, the present study indicated the RDP had significant antihypertensive efficacy and no side effects were found in vitro and in vivo. 


\section{Introduction}

Rice (Oryza sativa L.) represents one of the leading food crops in the world. A global annual production was about 480 million metric tons (milled rice basis) in 2015 [1]. It is cultivated today in more than 100 countries except Antarctica. It is the staple food for over half the world's population, mainly in Asian countries, where it provides a considerable proportion of the protein intake for millions of people [2-3]. The total food protein production of rice per hectare is second only to that of wheat, although the yield of utilisable protein is actually higher for rice than for wheat, due to the superior quality of rice proteins [3-4]. Rice is known to have nutritional, hypoallergenic and healthy properties, which are retained by Rice Dreg Peptides (RDP) derived from rice starch by-products that contains more than $50 \%$ protein content and is used as a protein source [5]. With the massive of rice starch syrups industry in China, RDP is available in large amounts and at minimal costs. RDP are currently used as animal feed with low economic benefits in China. In China, the development of efficient methods to recovering RDP for human consumption that could significantly increase economic and social benefits [6].

High blood pressure has now become a major global health concern. The disease affected approximately 73 million people in USA [7]. There will be about 1.56 billion people suffered with hypertension worldwide in 2025 [7-8]. At present, hundreds of peptides with antihypertensive activity have already been reported and novel peptides are also discovered every day [7]. These biofunctional peptides were derived from 35 major sources that include animal matrix as milk, egg, fish, pork, and chicken and plant as soybean etc. [7]. In general, plant-derived functional peptides are considered more safe and healthy compounds. They are low molecular weight, possess different biological activities, and are easily absorbed by the small intestine in human [9-10]. Usually, plant-derived functional peptides may show not only antioxidant properties but also a wide range of other physiologic and biological activities as anti-hypertension, anti-hypercholesterolemia, immunomodulation, and anti-microbial actions [5,9-10].

Angiotensin Converting Enzyme (ACE) increases blood pressure by converting the inactive angiotensin I (decapeptide) to the active angiotensin II (octapeptide). Several chemicals have been verified to act as anti-hypertensive drugs. These clinical anti-hypertensive drugs included as nifedipine, captopril, fosinopril, lisinopril etc., which act either by direct inhibition of ACE or block of the angiotensin II receptors. Although these chemicals are effective in the blood pressure control, however, there are many side effects found [11-12]. For the example, in the nifedipine intake, there are many side effects found as mild dizziness, flushing (warmth, redness, or tingly feeling), weakness, headache, mood changes, heartburn, nausea, tremors, muscle cramps, cough, wheezing, sore throat, stuffy nose, taste disturbance, skin rashes, kidney failure etc [7]
Besides chemical drugs, diet and lifestyle also play a significant role in the prevention of hypertension. Lots of small molecular peptides with antihypertensive activity have been discovered and many of these peptides are part of proteins present in our daily food. They are not toxic in general and may represent a new therapeutic strategy for the prevention and treatment of hypertension [7]. Hence, RDP were obtained from the rice dreg fermentation with Pediococcus pentosauceus L11 in this study. This novel RDP with anti-hypertensive activity was verified via in vitro ACE inhibition assay and in vivo SHRs animal experiment. There is a substantial interest in discovering RDP with antihypertensive activity in this study.

\section{Materials and Methods}

\section{Food by Products, Chemicals and Reagents}

Rice dreg (moisture: 80\%) was provided from rice winery in Miaoli, Taiwan. Pediococcus pentosauceus L11 (L11) was isolated from soil in Miaoli, Taiwan. Angiotensin-I-converting enzyme (ACE) and Hipurry-L-histidyl-L-leucine (HHL) were ordered from Sigma-Aldrich (St. Louis, MO, USA). Other chemicals used were of analytical grades.

\section{Fermentation of Rice Dreg}

Rice dreg was adjusted to $\mathrm{pH} 7.0$ using sodium hydroxide solution and fermented with 5\% sucrose and 10\% of L11 (final concentration of approximately $10^{6} \mathrm{CFU} / \mathrm{mL}$ ) and inoculated at $37^{\circ} \mathrm{C}$ for $48 \mathrm{~h}$. Later, these fermented samples were collected at post-fermentation 0,24 , and $48 \mathrm{~h}$, respectively. Then, the fermented rice dreg was centrifuged at $6,000 \times g$ for $30 \mathrm{~min}$ and removed insoluble materials. Collection of the supernatant was filtered (Advantec Grade No. 2 Qualitative Filter Paper) then stored at $-30^{\circ} \mathrm{C}$ until analysis.

\section{Measurement of RDP content}

Measurement of the peptide content of the fermented rice dregs was followed as the method of Tsai and Wu [13] with some modification. Twenty-five milliliter of working solution was prepared by mixing with $12.5 \mathrm{~mL}$ of $100 \mathrm{mM}$ borax, $1.25 \mathrm{~mL}$ of $20 \%(\mathrm{w} / \mathrm{w}$ ) sodium dodecyl sulfate, $20 \mathrm{mg}$ of $o$-phthaldialdehyde solution (dissolved in $0.5 \mathrm{~mL}$ of methanol) and $50 \mu \mathrm{L}$ of $\beta$-mercaptoethanol and then adjusted the volume to $25 \mathrm{~mL}$ with deionized water. Twenty-five microliters of the fermented rice dregs was mixed with $2 \mathrm{~mL}$ of working solution and incubated for 2 min at ambient temperature then measured on light absorbance at $340 \mathrm{~nm}$ with Hybrid Multi-Mode Reader $\left(\right.$ Synergy $^{\mathrm{TM}} \mathrm{H} 1$, BioTek, Winooski, USA). The peptide content was quantified by L-leucine (Difco Laboratories, Sparks, MD, USA) as standard.

\section{Determination of In Vitro ACE Inhibitory Activity}

The ACE inhibitory activity was assayed by Cushman and Cheung [14] with some modification. Each $450 \mu \mathrm{L}$ assay mixture contained 
the following components at the indicated final concentration: 100 mM borate buffer with $300 \mathrm{mM}$ Sodium chloride $150 \mu \mathrm{L}(\mathrm{pH} 8.3)$; $15 \mathrm{mM}$ HHL $150 \mathrm{~mL} ; 150 \mu \mathrm{L}$ of the fermented rice dregs and $8 \mathrm{mU}$ ACE. The mixture was incubated at $37^{\circ} \mathrm{C}$ for $30 \mathrm{~min}$. The reaction was stopped by adding $0.5 \mu \mathrm{L}$ of $1 \mathrm{M} \mathrm{HCl}$. The hippuric acid was extracted with ethyl acetate then removed ethyl acetate heat evaporation. The amount of hippuric acid was measured Hybrid Multi-Mode Reader (Synergy ${ }^{\mathrm{TM}}$ H1, BioTek, Winooski, USA) at 228 $\mathrm{nm}$. The inhibition was calculated by the method of Tsai and $\mathrm{Wu}$ [13]. ACE inhibitory activity was calculated by using the following formula:

$$
\begin{aligned}
& \quad \text { Inhibition }(\%)=A c-A s / A c-A b \\
& \text { Where, } \\
& \text { Ac = Absorbance of control sample }(\mathrm{HHL}+\text { buffer }+\mathrm{ACE}) \\
& \mathrm{As}=\text { Absorbance of sample solution }(\mathrm{HHL}+\text { sample }+\mathrm{ACE}) \\
& \mathrm{Ab}=\text { Absorbance of blank solution }(\mathrm{HHL}+\text { buffer })
\end{aligned}
$$

\section{Animal Care}

All animal experiments were approved by the Institutional Animal Care and Utilization Committee (IACUC) of Agricultural Technology Research Institute (ATRI), Xiangshan, Hsinchu, Taiwan and animal care was performed in compliance with the guidelines of IACUC. WKY rats and SHRs were freely fed a standard laboratory diet and the sterile drinking water and kept on a 12-h light/ dark cycle at $24-27^{\circ} \mathrm{C}$ and $60-70 \%$ humidity using an automatic control system in the GLP Animal Laboratory, Animal Technology Laboratories, ATRI, Xiangshan, Hsinchu, Taiwan.

\section{Detection of Blood Pressure of RDP-Administrated SHRs}

6-8 weeks old WKY rats $(n=10)$ and SHRs $(n=35)$ were raised in GLP Animal Laboratory, ATRI. The RDP via L11 fermentation was dissolved in physiological saline at two doses of 50 and $200 \mathrm{mg} / \mathrm{kg}$ body weight (BW). According to blood-pressure level, 35 SHRs were randomized into 4 groups [negative control group: 5 rats; positive control group (20 mg/kg/day nifedipine administration): 10 rats; $\mathrm{RDP}_{\text {low }}$ group (50 mg/kg BW RDP): 10 rats; $\mathrm{RDP}_{\text {high }}$ group (200 mg/ kg BW RDP): 10 rats]. On the other hand, 10 WKY rats were blank normal control group. RDP was administrated to SHRs by p.o. using disposable feeding needles (FN-9921, 20G × 1.5"; Kent Scientific, San Diego, CA, USA) once per day for 2 months. Twenty $\mathrm{mg} / \mathrm{kg} /$ day nifedipine was administrated for SHRs as the same method of RDP.

The same volume and frequency of physiological saline was administrated to WKY rats by p.o. using disposable feeding needles. The blood pressure values were measured for each group once a week. The efficacy of RDP on the blood pressure was compared with each group. Following p.o. of sample, the blood pressure of rats was measured by a tail-cuff method (Model MK-2000ST; Muromachi
Kikai, Tokyo, Japan) without warming rats in a chamber maintained at $38^{\circ} \mathrm{C}$ for $5 \mathrm{~min}$. Five times at a time and take the average for the detection of blood pressure.

\section{Statistical Analysis}

Values of ACE inhibitor activity and production concentration of RDP are reported as mean \pm Standard Deviation (S.D.). Values of blood pressure, body weight, and liver and kidney function indexes are represented as mean \pm Standard Error of the Mean (SEM). Statistical evaluation was performed using Student's t-test, one-way analysis of variance (ANOVA), and SAS 8.0 software. Differences between groups were considered statistically significant at ${ }^{*} p<0.05$.

\section{Results}

\section{The Most Ideal Fermentation Conditions of Rice Dregs}

The fermentation conditions as fermentation time (h), $\mathrm{pH}$ value, and bacterial concentrations ( $\mathrm{CFU} / \mathrm{mL}$ ) were screened. The fermentation time involved $0,5,24$ and $48 \mathrm{~h} ; \mathrm{pH}$ value included 7.00, 6.99, 5.13, and 5.17; bacterial concentrations involved $1.0 \times$ $10^{6}, 3.4 \times 10^{6}, 3.9 \times 10^{9}$, and $3.6 \times 10^{9}(\mathrm{CFU} / \mathrm{mL})$. The most ideal fermentation condition is set at fermentation time $(48 \mathrm{~h}), \mathrm{pH}$ value (5.17), and bacterial concentration $\left(3.6 \times 10^{9} \mathrm{CFU} / \mathrm{mL}\right)$. According to the most ideal fermentation conditions, the concentrations of RDP $(\mathrm{mg} / \mathrm{mL})$ under three fermentation time $(0,24$, and $48 \mathrm{~h})$ were respectively calculated as $24.14 \pm 0.09$ (fermentation at $0 \mathrm{~h}$ ), $31.79 \pm 0.42$ (fermentation at $24 \mathrm{~h}$ ), and $30.62 \pm 0.26$ (fermentation at $48 \mathrm{~h}$ ) (Table 2).

Table 1: Fermentation conditions of the rice dregs.

\begin{tabular}{|c|c|c|}
\hline $\begin{array}{c}\text { Fermentation time } \\
\text { (h) }\end{array}$ & $\mathbf{p H}$ & $\begin{array}{c}\text { Bacterial concentrations (CFU/ } \\
\mathbf{m L} \text { ) }\end{array}$ \\
\hline 0 & 7 & $1.0 \times 10^{6}$ \\
\hline 5 & 6.99 & $3.4 \times 10^{6}$ \\
\hline 24 & 5.13 & $3.9 \times 10^{9}$ \\
\hline 48 & 5.17 & $3.6 \times 10^{9}$ \\
\hline
\end{tabular}

\section{Effect of RDP on ACE Inhibitory Activity In Vitro}

The ACE inhibitory activity (\%) and $\mathrm{IC}_{50}$ (half maximal inhibitory concentration, $\mathrm{mg} / \mathrm{mL}$ ) of RDP was presented that 79.34 $\pm 4.61 \%$ and $15.21 \mathrm{mg} / \mathrm{mL}$ at $0 \mathrm{~h}$-fermentation, $84.78 \pm 7.72 \%$ and $18.75 \mathrm{mg} / \mathrm{mL}$ at $24 \mathrm{~h}$-fermentation, $96.70 \pm 5.85 \%$ and $15.83 \mathrm{mg} /$ $\mathrm{mL}$ at $48 \mathrm{~h}$-fermentation (Table 2). RDP production concentration and ACE inhibitory activity were dependently fermentation time. Zero h, $24 \mathrm{~h}$, and $48 \mathrm{~h}$-fermentation compared with each other were significantly different $(p<0.05)$ on RDP production concentration and ACE inhibitory activity (Table 2). 
Table 2: Effects of RDP on ACE inhibitory activity at various fermentation times.

\begin{tabular}{|c|c|c|c|}
\hline \multirow{2}{*}{ Fermentation time (h) } & \multirow{2}{*}{ Concentration of RDP (mg/mL) } & ACE inhibitory activity \\
\cline { 2 - 4 } & & Inhibitory (\%) & IC $_{\mathbf{5 0}}$ (mg/mL) \\
\hline 0 & $24.14 \pm 0.09^{\mathrm{a}}$ & $79.34 \pm 4.61^{\mathrm{a}}$ & 15.21 \\
\hline 24 & $31.79 \pm 0.42^{\mathrm{b}}$ & $84.78 \pm 7.72^{\mathrm{b}}$ & 18.75 \\
\hline 48 & $30.62 \pm 0.26^{\mathrm{c}}$ & $96.70 \pm 5.85^{\mathrm{c}}$ & 15.83 \\
\hline
\end{tabular}

Abbreviation: angiotensin I-converting enzyme (ACE); half maximal inhibitory concentration ( $\left.\mathrm{IC}_{50}\right)$; rice dreg peptides (RDP); standard deviation $(\mathrm{SD})$. Data were presented as mean $\pm \mathrm{SD}$. Different latters $(\mathrm{a}, \mathrm{b}$, and $\mathrm{c})$ was presented significant difference intergroups.

Effect of RDP on BW, Anti-hypertension, and Liver and

\section{Kidney Functions In Vivo}

The once per day- p.o. experiments with RDP in 6-8 weeks old SHRs. Thirty five SHRs were randomized into 4 groups: negative control group, positive control group (nifedipine administration), $\mathrm{RDP}_{\text {low }}$ group (50 mg/kg RDP), $\mathrm{RDP}_{\text {high }}$ group (200 mg/kg RDP). Ten WKY rats were blank normal control group. RDG was administrated by p.o. through gavage per day for 2 months. The BW and blood pressure values were measured for each group once a week.
The BW of all rats were increase continuously and were showed non-significantly different ( $p>0.05$ ) between 5 groups each other (Table 3). The blood pressure of SHRs before and after experiment in four groups were respectively $181.20 \pm 5.51 \mathrm{mmHg} ; 192.20 \pm$ $3.92 \mathrm{mmHg}$ (negative control group), $170.50 \pm 3.49 \mathrm{mmHg} ; 129.44$ $\pm 3.80 \mathrm{mmHg}$ (positive control group), $171.40 \pm 5.29 \mathrm{mmHg} ; 167.00$ $\pm 0.92 \mathrm{mmHg}\left(\mathrm{RDP}_{\text {low }}\right.$ group), and $169.70 \pm 6.69 \mathrm{mmHg} ; 159.70 \pm$ $1.01 \mathrm{mmHg}\left(\mathrm{RDP}_{\text {high }}\right.$ group). The efficacy of anti-hypertension of nifedipine is significantly higher than $\operatorname{RDP}(p<0.001)$.

Table 3: Change of body weight in rats during RDP administration.

\begin{tabular}{|c|c|c|c|c|c|}
\hline \multirow{2}{*}{ Week } & WKY rats & \multicolumn{4}{|c|}{ SHR } \\
\cline { 2 - 7 } & Normal control & Negative control & Positive control & RDP $_{\text {low }}$ & RDP $_{\text {high }}$ \\
\hline 0 & $200.07 \pm 2.98$ & $215.03 \pm 3.04$ & $211.28 \pm 3.11$ & $212.14 \pm 1.31$ & $219.38 \pm 2.65$ \\
\hline 1 & $250.61 \pm 3.66$ & $248.36 \pm 3.05$ & $247.90 \pm 2.88$ & $252.81 \pm 2.64$ & $262.99 \pm 3.58$ \\
\hline 2 & $267.20 \pm 3.95$ & $263.97 \pm 2.15$ & $260.30 \pm 3.12$ & $264.77 \pm 3.29$ & $270.70 \pm 4.43$ \\
\hline 3 & $281.75 \pm 4.60$ & $273.97 \pm 4.90$ & $273.90 \pm 3.03$ & $273.73 \pm 3.43$ & $282.94 \pm 4.87$ \\
\hline 4 & $294.04 \pm 5.27$ & $280.98 \pm 5.71$ & $293.27 \pm 10.73$ & $278.65 \pm 4.00$ & $290.47 \pm 4.84$ \\
\hline 5 & $309.72 \pm 4.90$ & $294.16 \pm 6.84$ & $294.05 \pm 4.03$ & $292.36 \pm 3.57$ & $299.00 \pm 5.85$ \\
\hline 6 & $315.21 \pm 4.71$ & $302.87 \pm 5.03$ & $302.38 \pm 4.63$ & $299.19 \pm 3.00$ & $307.34 \pm 4.61$ \\
\hline 7 & $324.31 \pm 4.34$ & $301.44 \pm 10.72$ & $308.14 \pm 4.55$ & $307.22 \pm 3.16$ & $312.22 \pm 5.57$ \\
\hline 8 & $335.00 \pm 4.77$ & $306.12 \pm 11.89$ & $310.51 \pm 4.88$ & $312.34 \pm 3.45$ & $297.55 \pm 4.24$ \\
\hline
\end{tabular}

Abbreviation: Wistar Kyoto (WKY); Spontaneously Hypertensive Rats (SHR); Standard Error of the Mean (SEM); Rice Dreg Peptides (RDP); Low Concentration of RDP $\left(\mathrm{RDP}_{\text {low }}\right)$; High Concentration of RDP $\left(\mathrm{RDP}_{\text {high }}\right)$. Data were presented as mean $\pm \mathrm{SEM}$.

The mean blood pressure in two RDP groups was significant ney functions of RDP-administrated SHRs were located at the norlower than negative control group $(p<0.01-p<0.001)$ (Figure 1). mal levels (Table 4).

Moreover, 4 indexes (GOT, GPT, BUN, and CRE) of the liver and kid-

Table 4: Effects of RDP on liver and kidney function indexes of WKY rats and SHR.

\begin{tabular}{|c|c|c|c|c|c|}
\hline \multirow{2}{*}{ Before } & WKY rats & \multicolumn{4}{|c|}{ SHR } \\
\cline { 2 - 6 } & Normal control & Negative control & Positive control & RDP $_{\text {low }}$ & RDP $_{\text {high }}$ \\
\hline GOT (U/L) & $101.60 \pm 10.92$ & $92.40 \pm 7.81$ & $85.500 \pm 2.29$ & $99.90 \pm 5.82$ & $89.50 \pm 4.41$ \\
\hline GPT (U/L) & $46.40 \pm 2.26$ & $33.80 \pm 0.73$ & $35.10 \pm 1.14$ & $39.10 \pm 1.67$ & $35.10 \pm 2.02$ \\
\hline BUN (mg/dL) & $20.12 \pm 0.87$ & $24.34 \pm 1.15$ & $28.42 \pm 1.15$ & $27.22 \pm 1.05$ & $29.34 \pm 0.92$ \\
\hline CRE (mg/dL) & $0.20 \pm 0.02$ & $0.18 \pm 0.02$ & $0.16 \pm 0.02$ & $0.15 \pm 0.02$ & $0.18 \pm 0.01$ \\
\hline \multicolumn{7}{|c|}{ After } \\
\hline GOT (U/L) & $79.00 \pm 5.54$ & $151.75 \pm 8.02$ & $91.44 \pm 5.89$ & $144.70 \pm 5.51$ & $110.90 \pm 8.86$ \\
\hline GPT (U/L) & $37.00 \pm 1.67$ & $51.25 \pm 4.75$ & $38.78 \pm 1.60$ & $42.90 \pm 1.57$ & $40.30 \pm 1.61$ \\
\hline BUN (mg/dL) & $17.76 \pm 0.66$ & $21.55 \pm 0.70$ & $20.30 \pm 0.96$ & $19.20 \pm 0.57$ & $22.02 \pm 0.58$ \\
\hline CRE (mg/dL) & $0.24 \pm 0.02$ & $0.28 \pm 0.02$ & $0.20 \pm 0.00$ & $0.25 \pm 0.02$ & $0.23 \pm 0.02$ \\
\hline
\end{tabular}

Abbreviation: Wistar Kyoto (WKY); Spontaneously Hypertensive Rats (SHR); Standard Error of the Mean (SEM); Glutamic- 
Oxaloacetic Transaminase (GOT); Glutamic-Pyruvic Transaminase (GPT); Blood Urea Nitrogen (BUN); Creatinine (CRE); Rice Dreg Peptides (RDP); Low Concentration of RDP $\left(\mathrm{RDP}_{\text {low }}\right)$; High Concentration of RDP (RDP $\left.{ }_{\text {high }}\right)$. Data were presented as mean \pm SEM.

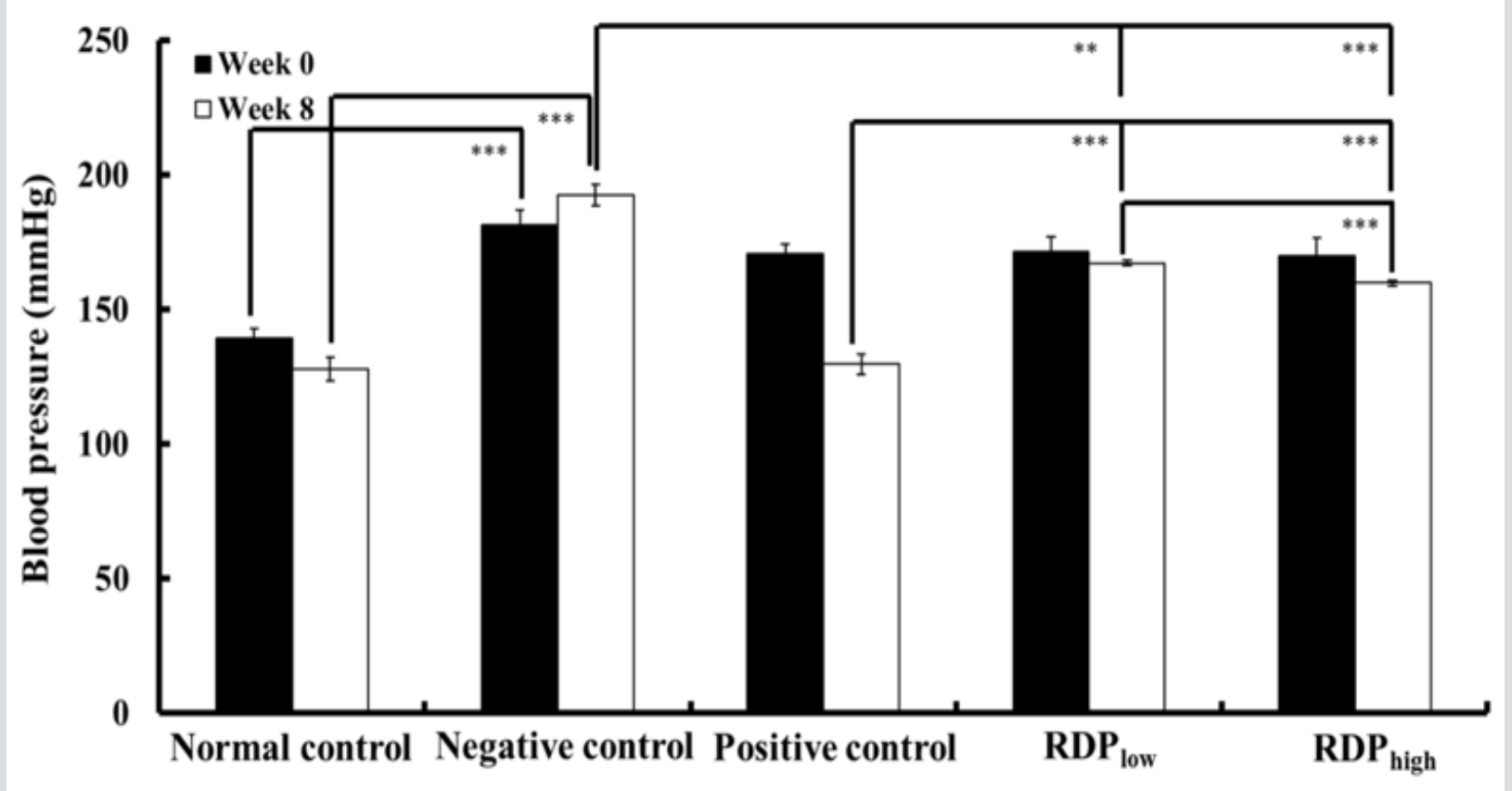

Figure 1: Efficacy of RDP on the anti-hypertension in vivo. Thirty-five SHRs were randomized into 4 groups [negative control group: 5 rats; positive control group $\left(20 \mathrm{mg} / \mathrm{kg} /\right.$ day nifedipine): 10 rats; $\mathrm{RDP}_{\text {low }}$ group ( $50 \mathrm{mg} / \mathrm{kg}$ RDP): 10 rats; $\mathrm{RDP}_{\text {high }}$ group (200 mg/kg RDP): 10 rats]. Ten WKY rats were blank normal control group.

\section{Discussion}

Functional peptides can be isolated from the natural food or their by-products. These natural food sources include mainly animal matrix as milk, egg, meat, fish, etc. and plants as cereal, wheat, rice, garlic, spinach, grapes, etc. [15-23]. These functional peptides have also been reported from various biological processes such as enzymatic hydrolysis, fermentation, and chemical synthesis [7,24-26]. At present, lots of chemical drugs have been designed to act on anti-hypertension. Although these drugs are very effective in controlling blood pressure, there are a lot of side effects associated with them. Hence, search of a novel anti-hypertensive compound with no side effects is need. Rice is a major and fundamental cereal source of energy and protein in the world. It is consumed as a staple food for about half of the world's population in over 100 countries. Rice protein has unique nutritional and hypoallergenic properties compared to other plant-sourced protein [27-28] and is suitable as a hypoallergenic protein source to replace milk and soy infant formulas [6,28-29]. Rice manufacturing industry produces large volumes of co- and by-products, which are generally undervalued and under-utilised. Although rice-sourced by-products were cheap. However, it can be renewable to producing the abundant antioxidant and bioactive compounds/peptides [5]. Currently, ricesourced by-products are mostly used as animal feed. These proteins of rice-sourced by-products were as a valuable source for the recovery of antioxidant peptides following whole cell or proteolytic enzyme treatments [5].

Many ACE inhibitory peptides have been characterized from food proteins such as gelatin, maize, fish, eggs, pea, and whey protein [30]. In this study, the source of RDP was rice dregs via lactic acid bacterial fermentation. This RDP is a valuable source for anti-hypertension according to the data of in vitro ACE inhibitory activity and in vivo animal experiment with SHRs. We have successfully R\&D to evaluate the rice sourced by-products became the renewable bio-matrix and produced the anti-ACE and anti-hypertensive peptides (RDP). RDP with ACE inhibitory activity was mainly produced by many factories such as monosodium glutamate factory, glucose factory, fermentation industry etc. Commonly, rice dregs are severed as animal feed and they can cause environmental pollution problem. Moreover, rice dregs contain at least 65\% protein content, which is higher than soybean protein content.

Therefore, rice dregs are good materials for producing the anti-hypertensive peptides [30]. In this study, ACE inhibitory peptides sourced from rice dregs has some effect on blood pressure regulation in vivo with SHRs. Additionally, Increase BW and normal liver and kidney functions of RDP-administrated SHRs were found in this study. We have found a safer, effective, and economical ACE inhibitor (RDP) for the remedy of hypertension. So, rice dregs-derived 
ACE inhibitory peptides via the lactic acid bacterial fermentation are safer and more efficient substitution for human health.

\section{Conclusion}

Our study mainly focused on the ACE inhibitory activity and anti-hypertension efficacy of RDP. The present study indicated the RDP had significant antihypertensive efficacy and no side effects were found in vitro and/or in vivo. Pediococcus pentosauceus L11-fermentated products (RDP) from rice dregs might serve as alternative sources of dietary health care products with good nutritional quality, safety, and protection against hypertension. Our data might contribute to further research into food derived antihypertensive compounds, meanwhile it also provides some reference for the clinical drug use of RDP in traditional Chinese medicine.

\section{Acknowledgement}

There is no conflict of interest to declare. Authors wish to thank the Council of Agriculture in Taiwan (Executive Yuan) for supporting this study (105AS-16.4.1-ST-a1; 106AS-16.4.1-ST-a1; 106AS-19.4.2ST-a1; 107AS-15.4.3-ST-a1; 107AS-13.4.1-ST-a1; 108AS-12.4.1ST-a1). Thanks to all the people who joined and helped in this study.

\section{References}

1. USDA (2015) Grain: World markets and trade. August 2015. Department of Agriculture, Foreign Agricultural Service. Washington, DC: USA

2. Muthayya S, Sugimoto JD, Montgomery S, Maberly GF (2014) An overview of global rice production, supply, trade, and consumption. Ann N Y Acad Sci 1324: 7-14.

3. Amagliani L, O’Regan J, Kelly AL, O’Mahony JA (2017) The composition, extraction, functionality and applications of rice proteins: a review. Trends Food Sci Technol 64: 1-12.

4. Childs NW (2004) Production and utilization of rice. In: Champagne ET (Eds.), Rice: Chemistry and Technology ( $3^{\text {rd }}$ edn,). St. Paul, MN: American Association of Cereal Chemists, p. 1-23.

5. Ferri M, Graen Heedfeld J, Bretz K, Guillon F, Michelini E, et al. (2017) Peptide fractions obtained from rice by-products by means of an environment-friendly process show in vitro health-related bioactivities. PLoS One 12: e0170954.

6. Zhao Q, Selomulya C, Xiong H, Chen XD, Li X, et al. (2014) Rice dreg protein as an alternative to soy protein isolate: comparison of nutritional properties. Int J Food Prop 17: 1791-1804.

7. Kumar R, Chaudhary K, Sharma M, Nagpal G, Chauhan JS, et al. (2015) AHTPDB: a comprehensive platform for analysis and presentation of antihypertensive peptides. Nucleic Acids Res 43(Database issue): D956-D962.

8. Chockalingam A, Campbell NR, Fodor JG (2006) Worldwide epidemic of hypertension. Can J Cardiol 22: 553-555.

9. Zhao Q, Xiong H, Selomulya C, Chen XD, Zhong H, et al. (2012) Enzymatic hydrolysis of rice dreg protein: effects of enzyme type on the functional properties and antioxidant activities of recovered proteins. Food Chem 134: 1360-1367.

10. Cavazos A, de Mejia EG (2013) Identification of bioactive peptides from cereal storage proteins and their potential role in prevention of chronic diseases. Compr Rev Food Sci Saf 12: 364-380.

11. Jurima Romet M, Huang HS (1993) Comparative cytotoxicity of angiotensin-converting enzyme inhibitors in cultured rat hepatocytes. Biochem Pharmacol 46: 2163-2170.
12. Yeung E, Wong FS, Wanless IR, Shiota K, Guindi M, et al. (2003) Ramiprilassociated hepatotoxicity. Arch Pathol Lab Med 127: 1493-1497.

13. Tsai SJ, Wu IY (2009) Effect of yeast strains and distillation on nutritional composition of rice dregs. J Taiwan Agric Res 58: 106-131.

14. Cushman DW, Cheung HS (1971) Spectrophotometric assay and properties of the angiotensin-converting enzyme of rabbit lung. Biochem Pharmacol 20: 1637-1648.

15. Matsui T, Li CH, Tanaka T, Maki T, Osajima Y, et al. (2000) Depressor effect of wheat germ hydrolysate and its novel angiotensin I-converting enzyme inhibitory peptide, Ile-Val-Tyr, and the metabolism in rat and human plasma. Biol Pharm Bull 23: 427-431.

16. Seppo L, Jauhiainen T, Poussa T, Korpela R (2003) A fermented milk high in bioactive peptides has a blood pressure-lowering effect in hypertensive subjects. Am J Clin Nutr 77: 326-330.

17. Yang Y, Marczak ED, Yokoo M, Usui H, Yoshikawa M (2003) Isolation and antihypertensive effect of angiotensin I-converting enzyme (ACE) inhibitory peptides from spinach Rubisco. J Agric Food Chem 51: 48974902.

18. Yamamoto N, Ejiri M, Mizuno S (2003) Biogenic peptides and their potential use. Curr Pharm Des 9: 1345-1355.

19. Chen Q, Xuan G, Fu M, He G, Wang W, et al. (2007) Effect of angiotensin I-converting enzyme inhibitory peptide from rice dregs protein on antihypertensive activity in spontaneously hypertensive rats. Asia Pac J Clin Nutr 16 Suppl 1: 281-285.

20. Jauhiainen T, Korpela,R (2007) Milk peptides and blood pressure. J Nutr 137: 825S-829S.

21. Kitts DD, Weiler K (2003) Bioactive proteins and peptides from food sources. applications of bioprocesses used in isolation and recovery. Curr Pharm Des 9: 1309-1323.

22. Saito T (2008) Antihypertensive peptides derived from bovine casein and whey proteins. Adv Exp Med Biol 606: 295-317.

23. Nakahara T, Sano A, Yamaguchi H, Sugimoto K, Chikata H, et al. (2010) Antihypertensive effect of peptide-enriched soy sauce-like seasoning and identification of its angiotensin I-converting enzyme inhibitory substances. J Agric Food Chem 58: 821-827.

24. Inoue K, Gotou T, Kitajima H, Mizuno S, Nakazawa T, et al. (2009) Release of antihypertensive peptides in miso paste during its fermentation, by the addition of casein. J Biosci Bioeng 108: 111-115.

25. Quiros A, Hernandez Ledesma B, Ramos M, Martin Alvarez PJ, Recio I (2012) Short communication: production of antihypertensive peptide HLPLP by enzymatic hydrolysis: optimization by response surface methodology. J Dairy Sci 95: 4280-4285.

26. Koyama M, Naramoto K, Nakajima T, Aoyama T, Watanabe M, et al. (2013) Purification and identification of antihypertensive peptides from fermented buckwheat sprouts. J Agric Food Chem 61: 3013-3021.

27. Eggum BO, Cabrera MIZ, Juliano BO (1993) Protein and lysine digestibility and protein quality of cooked Filipino rice diets and milled rice in growing rats. Plant Foods Hum Nutr 43: 163-170.

28. Fiocchi A, Travaini M, D’Auria E, Banderali G, Bernardo L, et al. (2003) Tolerance to a rice hydrolysate formula in children allergic to cow's milk and soy. Clin Exp Allergy 33: 1576-1580.

29. Reche M, Pascual C, Fiandor A, Polanco I, Rivero Urgell M, et al. (2010) The effect of a partially hydrolysed formula based on rice protein in the treatment of infants with cow's milk protein allergy. Pediatr Allergy Immunol 21: 577-585.

30. He GQ, Xuan GD, Ruan H, Chen QH, Xu Y (2005) Optimization of angiotensin I-converting enzyme (ACE) inhibition by rice dregs hydrolysates using response surface methodology. J Zhejiang Univ SCI 6B: 508-513. 


\section{ISSN: 2574-1241}

DOI: 10.26717/BJSTR.2019.18.003121

Meng Hwan Lee. Biomed J Sci \& Tech Res

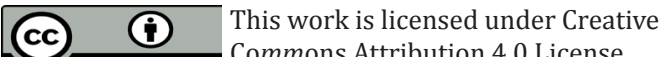

Submission Link: https://biomedres.us/submit-manuscript.php

$\begin{array}{ll}\text { BIOMEDICAL } & \text { Assets of Publishing with us } \\ \text { RESEARCHES } & \text { Global archiving of articles } \\ \text { - Immediate, unrestricted online access }\end{array}$

